\title{
SOBRE A EFICÁCIA DE ANJOS EVANESCENTES: teologia e política em Walter Benjamin
}

\author{
Marcelo Santana Ferreira ${ }^{1}$ \\ Marina Harter Pamplona ${ }^{2}$
}

\begin{abstract}
Resumo: No presente artigo, nos propomos a indicar, em parte da obra de Walter Benjamin, o que chamamos de uma angeologia, relacionando-a com a experiência da infância, o que se configura como a possibilidade de defesa de uma relação entre infância e religião. Apoiando-se na mística judaica, Benjamin faz uma conexão singular entre materialismo histórico e teologia, defendendo uma compreensão política da infância e uma aliança crítica entre a teologia e o materialismo histórico. $\mathrm{O}$ pensador sugere caminhos férteis para a crítica da noção de ingenuidade infantil e garante uma posição privilegiada aos profanos usos infantis da tradição nas brincadeiras.
\end{abstract}

Palavras-chave: Infância; Walter Benjamin; Angeologia.

\section{SOBRE LA EFICACIA DE ÁNGELES EVANESCENTES: teologia y política en Walter Benjamin}

Resumen: En el presente artículo, nos proponemos indicar, en parte de la obra de Walter Benjamin, lo que llamamos una angeología, relacionándola con la experiencia de la infancia, lo que se configura como la posibilidad de defensa de una relación entre infancia y la religión. Apoyandóse en la mística judía, Benjamín hace una conexión singular entre materialismo histórico y teología, defendiendo una comprensión política de la infancia y una alianza crítica entre la teología y el materialismo histórico. El pensador sugiere caminos fértiles para la crítica de la noción de ingenuidad infantil y garantiza una posición privilegiada a los profanos usos infantiles de la tradición en las bromas.

Palabras clave: Infancia; Walter Benjamin; Angeologia.

"Voltando de um campo de concentração, acaba de entrar na grande clínica do outro lado da rua uma militante comunista. Mais tarde, ela me contará:

- Eu tentava viver...As primeiras vozes que ouvi eram dos seus moleques. Sabia que estava em um bairro burguês e as vozes que ouvia eram gírias do bairro onde eu morava quando era pequena. Pensei durante vários dias que era o delírio antes da morte, lembranças se debatendo em meus ouvidos. Mas o fato é que não reconhecia as canções... Admiti que o que estava ouvindo era algo novo.

- Estou contente, sabe, [...], contente de ter ouvido suas vozes, as primeiras.

A mulher que me dizia isso estava a um passo da morte e do suplício." (DELIGNY, Fernand, 2018, p. 54)

\section{Introdução}

Uma sobrevivente de um campo de concentração nazista ouve em seu leito no hospital vozes que se distanciam do tom dominante com que se fala a língua nativa em um bairro burguês. São vozes de crianças inadaptadas, cumprindo um tempo de

\footnotetext{
${ }^{1}$ Professor Associado de Psicologia Social da UFF/ Instituto de Psicologia. Professor do Programa de Pós-graduação em Psicologia: Estudos da Subjetividade da UFF/Niterói.

${ }^{2}$ Graduada em Psicologia pela UFF, Mestranda em Psicologia no Programa de Pós-graduação em

Psicologia: Estudos da Subjetividade.
} 
institucionalização sob os cuidados de um homem adulto que não as subestima como representantes ferozes da produção de redes improváveis. Crianças inadaptadas, loucos, delinquentes constituem, junto ao especialista, alianças com vagabundos que citam, ruidosamente, a precariedade arrogante dos mecanismos de inclusão em curso no sistema capitalista. São as crianças precoces, imprestáveis que indicam as melhores possibilidades de vínculos em que se pode aspirar a uma nova relação com o tempo. Estas crianças são o resto, evocado no texto de Deligny (2018). Algumas décadas antes da publicação do diário de Fernand Deligny em um estabelecimento para crianças e jovens delinquentes na França, foi o pensador Walter Benjamin quem fez jus ao encontro imprevisto entre adultos e crianças - e, ainda mais, entre crianças e anjos personagens sem pompa, imagens inacabadas da relação entre a imanência do cotidiano e as brechas frágeis da salvação ou da lembrança. As vozes de crianças inadaptadas são tanto a reiteração da finitude quanto a possibilidade de insistir na vida e na partilha. As vozes viabilizam que a mulher exaurida se conecte com uma lembrança de infância. As crianças povoam, insistentemente, alguns textos do pensador judeu alemão Walter Benjamin, chegando atrasadas aos encontros e acontecimentos, alcançando menos do que um terço do que o olhar consegue abarcar, deixando-se seduzir por palavras que não foram necessariamente endereçadas a elas. São a estas crianças que nos voltaremos no presente artigo, testemunhas futuras da presença do que restou do tempo. Uma condição como esta sustém a possibilidade de entendermos a relação entre infância e religião, mesmo que para defendermos a conexão lancemos mão de um pensador que se estabeleceu no limiar do materialismo com a magia. A referência à mística judaica, em Walter Benjamin, não serve como abrigo para a caracterização religiosa de sua obra. Trata-se, muito mais, da implosão de fronteiras com vistas à defesa de uma concepção de tempo em que recordação e esperança permitam a interrupção da cronologia, na base do sistema capitalista e, mesmo, das perspectivas críticas em relação ao projeto de continuidade entre acumulação de riquezas e barbárie. Para vincular de modo crítico esperança e recordação, evocaremos a radicalidade dos nascimentos e das lembranças do resto de tempo que ainda requerem reconhecimento para serem devidamente desdobradas. Não são imagens sociologizantes que evocaremos, mas abrigos frágeis da relação entre infância e políticas do tempo, enfatizando a passagem do pensamento de Walter Benjamin por alguns aspectos da mística judaica. Muito precocemente, dedicamos aos que nascem um conjunto de expectativas que visam a regulação da vida. Mas, talvez, o nascimento nos coloque um problema quanto à origem, quanto ao 
passado e, fundamentalmente, quanto ao tempo. Tornarmo-nos habituados aos nascimentos no mundo tem sido tarefa de uma força histórica que nos impele sempre adiante, indicando os paradoxos da relação instituída entre estabelecimentos como a escola e experiências como a infância. Trata-se de prevê-los, antecipá-los, introduzi-los rapidamente na linearidade morosa do tempo - tal qual é entendido nas ciências modernas. Em Pedagogia profana, Larrosa (2016) explicita o poder que o mundo dos adultos exerce sobre aqueles que mal chegaram ao mundo, são submergidos com nossos projetos, expectativas, temores, compreensões. O nascimento é introduzido, portanto, na "continuidade da história do mundo" (LARROSA, 2016, p. 187), no entanto, é o acontecimento de um outro diante de nós.

\begin{abstract}
Desse ponto de vista, uma criança é algo absolutamente novo que dissolve a solidez do nosso mundo e que suspende a certeza que nós temos de nós próprios. Não é o começo de um processo mais ou menos antecipável, mas uma origem absoluta, um verdadeiro início. Não é o momento em que colocamos a criança numa relação de continuidade conosco e com nosso mundo (para que se converta em um de nós e se introduza em nosso mundo), mas o instante da absoluta descontinuidade, da possibilidade enigmática de que algo que não sabemos e que não nos pertence inaugure um novo início. Por isso, o nascimento não é um momento que se possa situar numa cronologia, mas aquilo que interrompe toda cronologia (LARROSA, 2016, p. 187).
\end{abstract}

Reconhecer a alteridade do nascimento de um outro, implicaria, portanto, tomálo como enigma. Neste sentido, Larrosa se alia à Hannah Arendt como oportunidade de tomar o nascimento como a "salvaguarda da renovação do mundo". Talvez, por isso, seja possível pressentir a energia que discursos totalitários desprendem para o investimento na educação e na infância, a fim de aniquilar, no limite, a novidade no nascimento. Assim, Larrosa (2016, p. 191) explicita uma das faces do totalitarismo: “ídolo ávido de sangue infantil, cujos nomes são Progresso, Desenvolvimento, Futuro e Competitividade". No entanto, Hannah Arendt faz a luminosidade do milagre repousar sobre a atividade humana do nascer no mundo, percorrendo a narrativa bíblica por dentro, e tomando o próprio nascimento de Jesus como emblema de um "nascimento inesperado que interrompe a segurança do mundo e a continuidade da história" (LARROSA, 2016, p. 189).

Em uma das imagens da infância berlinense de Walter Benjamin (1987), é também um dia desse nascimento que ganha forma de uma narrativa, um nascimento reiterado e investido ano após ano pelo Capital e pelas famílias asseguradas em suas casas - em torno da grande árvore iluminada. Trata-se do Anjo de Natal. O conforto da 
festividade é fragilizado pelo próprio aparecimento do mercado de Natal, em que as famílias mais pobres vendiam, nas portas das casas da burguesia, os adereços que comporiam a festa. À espera do soar das horas que iniciariam a comemoração, a criança não acendeu a lâmpada do quarto e olhava para as janelas do lado de fora, deixando o olhar pousar sobre as janelas escuras das casas dos pobres:

Então de novo me veio à lembrança a distribuição de presentes organizada por meus pais; porém, mal me desviara da janela com o coração aflito, como só o faz a proximidade de uma alegria certeira, senti uma presença estranha no quarto. Não era nada além de uma aragem, de modo que as palavras que formaram em meus lábios foram como as pregas que um velame inerte lança subitamente à brisa fresca: 'O Menino Deus volta todos os anos/ À terra onde vivemos nós, humanos'. Com tais palavras se volatizou também o anjo que nelas começara a tomar forma. Porém não fiquei mais tempo naquele quarto vazio. Chamaram-me para o aposento defronte, no qual a árvore entrara gloriosa, o que dela me alienou até que, desprovida de seu suporte, terminou a festa enterrada na neve ou reluzente sob a chuva. (BENJAMIN, 1987, p. 121-122)

A presença do Anjo que logo se dissipa diante da imposição de outras iluminações inicia a dispersão da segurança dos interiores das moradas burguesas, como uma "brisa" que sopra nas velas de um barco a possibilidade de traçar outro curso na história; uma aparição frágil e fugaz:

[...] como a volta anual do menino Jesus na Terra que corre o risco de passar desapercebida, paradoxalmente sufocada pela rotina das festividades. O menino que a pressentirá sairá do seu quarto e se juntará à festa; mas algo fica como um mal-estar em relação a seus esplendores, como uma distância entre a criança, ávida de presentes, e si mesma, distância oriunda da escuridão das janelas do pátio e da imperceptível presença de uma alteridade radical (GAGNEBIN, 1997, p. 132).

\section{Os anjos em Walter Benjamin}

A aproximação do pensamento de Walter Benjamin à mística judaica não pode se realizar sem o reconhecimento de que o próprio pensador ensaiou diferentes modos de relação entre o sagrado e o profano, diferentes tentativas de defender uma temporalidade estendida em relação à concepção mecanicista de tempo subjacente as historiografias dominantes entre o final do século XIX e a primeira metade do século XX na Europa Ocidental. É se aproximando de uma interpretação da mística judaica e dos estudos de um amigo, Gershom Scholem, sobre a Cabala e introduzindo uma cesura 
no tempo homogêneo e vazio que Walter Benjamin indicará a fertilidade de constituir um limiar entre a teologia e o materialismo histórico. Os anjos surgirão de maneira singular em seus escritos. Apropriaremo-nos de alguns momentos desse surgimento. As imagens propostas nos parágrafos anteriores nos indicam a peculiaridade da atividade reminiscente, adotada nos textos autobiográficos e no texto derradeiro da obra benjaminiana, as célebres Teses sobre o conceito de história. A presença dos anjos se exprime como esforço de escrita/pensamento reiterado na indicação de um vestígio do sagrado no profano. Prestar atenção ao que se dissolvia no Natal é uma imagem que emerge na atividade reminiscente de um adulto que se detém no texto diante do que, silenciosamente, sobrou do passado. Não são apenas metáforas, mas imagens que resultam da atividade crítica diante das dicotomias impostas ao pensamento: dentro/fora, eu/mundo, si mesmo/alteridade radical. Ainda nos referindo aos textos autobiográficos, em que reconhecemos a passagem do biográfico ao político, encontramos em Walter Benjamin (1987) a experiência tateante da infância assombrada pelo ritmo frenético da cidade grande regulado pela velocidade e voracidade do progresso.

No texto Acidentes e crimes, Benjamin (1987) evoca a criança que espreita os signos da Desgraça, retumbando em seu pensamento a imagem do Anjo da Morte, crivada na tentativa de impedir a novidade portada por todo nascimento e que indicava o esforço de Herodes de interromper a vinda do Messias ${ }^{3}$. Na cidade moderna, mais especificamente em Berlim do século XIX, o infante Benjamin talvez tenha sentido um terror parecido com aquele dos judeus que aguardavam o nascimento dos seus primogênitos. Na moderna cidade, os vidros opacos das ambulâncias, as grades e as janelas fechadas das casas e hospitais em que padeciam homens e mulheres muito doentes escondiam aspectos da vida e da morte inalcançáveis pelas crianças. Mas, ao mesmo tempo, protegiam uma temporalidade forjada pela imaginação política profana, ao indicar-se que sempre se chegava um pouco atrasado às cenas turbulentas da cidade. Talvez os doentes pudessem se recuperar e as janelas pudessem ser abertas. Talvez houvesse um rastro de esperança tardia e de continuidade imprevista ao que se aproximava do fim. Trata-se de uma imagem e, ao mesmo tempo, da articulação de uma

\footnotetext{
3 De acordo com a narrativa bíblica, Herodes se atemorizava com a possibilidade de nascimento de alguém que colocasse em risco o seu próprio poder e, por isso, queria se antecipar a todo nascimento de primogênitos, seguindo a profecia que havia lhe sido transmitida. Herodes quer impedir que a novidade radical interrompa a continuidade de seu reinado, revelando um dos modos como se tenta interromper, de acordo com uma interpretação da tradição judaico-cristã, a salvação.
} 
tarefa política para a ciência histórica. Pergunta-se Benjamin:

Mas será que o Anjo da Morte cumpria o seu dever? Ou será que um belo dia os postigos se abriam, e o doente grave assomava à janela como convalescente? Não se teria gostado de facilitar a passagem à Morte, ao fogo ou apenas ao granizo que tamborilava nos vidros de minha janela sem jamais perfurá-los? (BENJAMIN, 1987, p. 131)

Jeanne Marie Gagnebin (1997) sugere, em seu belo comentário sobre o texto benjaminiano citado, que o terror que espreitava o menino burguês talvez fosse o de que “[...] nada vá realmente até seu cumprimento" (p. 130), viabilizando que, futuramente, o pensador defendesse imagens da fraqueza de toda tradição totalizadora, apontando-se para uma doença da tradição. Trata-se da defesa de uma impotência e, ao mesmo tempo, de uma nova tarefa política ao pensamento e aos homens. Na angeologia benjaminiana, a humanidade pode ajudar aos anjos, decifrando os signos que suas presenças fulgurantes carregam. Para Gagnebin (1997), os anjos disformes, imperfeitos e canhestros são parentes de personagens ineficazes e opacos da obra de $\mathrm{Kafka}^{4}$. Na aproximação com o problema que ora colocamos, a presença dos anjos indica a preocupação teórica e política com a interrupção da "infelicidade cotidiana" para a instauração do "[...] perigoso transtorno da felicidade" (GAGNEBIN, 1997, p. 130). Para dar prosseguimento ao que fora interrompido, instaura-se a defesa de uma atividade reminiscente que não se torna ressentida, uma vez que o próprio passado se torna um objeto aberto à experiência do estudioso/estudiosa que se sente convocado(a) a defender uma imagem do tempo como algo espesso e não homogêneo e vazio. Ao tratar de temas que, em sua aparência, estão vinculados a estudos religiosos, Walter Benjamin propicia que entendamos a infância como experiência de abertura aos signos de interrupção da continuidade abstrata. Benjamin nos fornece bases epistemológicas e políticas para a interpretação da infância como experiência que clama pela

\footnotetext{
4 Em Jeanne Marie Gagnebin encontramos muitas referências importantes para o artigo que escrevemos. Embora seja um caminho adjacente ao argumento que buscamos defender aqui, não podemos deixar de considerar a importância do pequeno artigo de Gagnebin (1997) que faz numerosas e férteis menções a momentos muito valiosos da obra do pensador judeu alemão, como a consistente reflexão proposta sobre a obra de Franz Kafka. Uma das citações de Gagnebin se direciona à correspondência trocada entre Benjamin e Scholem, em que se destacam diálogos mantidos sobre as interpretações muitas vezes divergentes da obra de Kafka pelos dois amigos. Gostaríamos de destacar a carta que Walter Benjamin envia a Scholem em 12 de junho de 1938, depois de uma longa discussão acerca de Kafka. Na carta em destaque, Benjamin faz uma valiosa interpretação do tema dos anjos que, embora não caiba no corpo do artigo, pode interessar a estudos sobre a relação entre Benjamin e Kafka. Benjamin (1980, p. 303) afirma na carta que "[...] o mundo de Kafka, tão alegre e povoado de anjos, é o complemento exato para uma época que se dispõe a aniquilar em grande escala os habitantes deste planeta.”. O horror e a atualidade da arguta observação de Benjamin ao amigo nos leva a admitir o problemático sentido de atualidade no pensador e a fecunda importância do tema dos anjos, tratado criticamente pelo pensador.
} 
incompletude e pela defesa do trabalho obstinado sobre o tempo, transtornado pelo profícuo perigo da felicidade. Temas teológicos são flagrados no avanço do pensamento benjaminiano. E a infância acolhe a magnitude dos temas, por evocar os limiares que escapam das divisões binárias.

A atividade reminiscente na concepção historiográfica proposta por Walter Benjamin se consolida, certamente, com a articulação de uma imagem do tempo que é extensão e compressão de uma só vez. A extensão do tempo só se torna viável por intermédio de uma demora no exercício reflexivo-crítico sobre vestígios de outrora, com o que se pode forjar esboços do futuro. Os vestígios são fragmentos de uma temporalidade permanentemente negada pelos signos do progresso e do continuísmo. Ao citar a infância como abertura ao inaudito na composição do texto, é recolocando questões teológicas que Walter Benjamin pode nos fornecer, como já vislumbramos, possibilidades de vinculação entre a experiência da infância e a relação com o imprevisto, na crítica imanente à noção de novidade no sentido jornalístico e burguês. Que a defesa do trabalho histórico se escore em uma imagética de anjos imperfeitos não nos parece nada contraditório. Tal conexão nos dirige ao entendimento do limiar entre sagrado e profano que Benjamin visou defender.

Os anjos são personagens de uma temporalidade vacilante, coadunando-se com a incerteza que subsidia o jogo infantil que, embora embalado pela repetição, mantém seu halo de acolhimento do que é singular. O jogo, no caso da brincadeira infantil, também é uma forma de inclusão da descontinuidade no vazio do tempo que só se aparenta consigo mesmo. A respeito dessa descontinuidade instaurada pela intrusão do jogo na vida humana, Agamben (2005) dedica uma de suas reflexões:

Vimos, de fato, que tudo aquilo que pertence ao jogo pertenceu, outrora, à esfera do sagrado. Mas isto não exaure a esfera do jogo. Os homens continuam, na verdade, a inventar jogos, e pode-se jogar até mesmo com o que, no passado, pertenceu à esfera prático-econômica. Um olhar sobre o mundo dos brinquedos mostra que as crianças, estes belchiores da humanidade, brincam com qualquer velharia que lhes cai nas mãos, e que o jogo conserva assim objetos e comportamentos profanos que não existem mais. Tudo que é velho, independentemente de sua origem sacra, é suscetível de virar brinquedo. (AGAMBEN, 2005, p. 85).

"Miniaturizando o presente" ou "distorcendo o passado", o brinquedo é algo histórico - ou a materialização da historicidade; portanto, é na atividade do jogo que o limiar entre teologia e materialismo histórico parece se condensar, atividade que tem como produto o resíduo entre o que já foi e agora não é mais. Assim, a argumentação de 
Agamben nos fornece as feições de uma perspectiva para a história que é objeto da brincadeira das crianças. O jogo, nesse sentido, efetua-se por uma fragmentação do sagrado, dirigindo-se para o agir e desprendendo-se, tanto do propósito quanto do sentido originário de objetos e palavras outrora pertencentes à esfera do sagrado. Tratase da criação, sempre imprevisível e não totalizável, de novos significantes.

A irrupção das feições não totalizáveis das ruas e dos objetos, na experiência infantil, está carregada de cesura, como expressão de uma imagem do tempo que muito interessa aos estudos de Walter Benjamin e, especificamente, ao campo em que ora formulamos uma questão. Sem recair em nenhum dogmatismo, a proposição política de Benjamin a respeito da infância está assentada em uma idealização e carrega, ao mesmo tempo, a imanência da situação histórica de uma criança burguesa no limiar do século XX. O sopro de esperança que traz os anjos para os textos de Benjamin se dirige a uma espécie de restituição da materialidade dos objetos, tornados mercadorias na infernal produção de novidades no cerne do sistema de produção capitalista. Os anjos não trazem a integralidade de uma salvação definitiva, mas estão conectados com a importância da interrupção. Lembrando-se, mais uma vez, da sua infância em Berlim, Benjamin (1987) evoca no texto Mendigos e prostitutas a sua posição sempre "meio passo atrás" da caminhada da mãe pela cidade, persistindo na atitude crítica em relação a sua própria classe, quando se foi tecendo a obra que reivindicava - ainda reivindica um desvio em relação tanto à continuidade quanto à novidade. Desde a infância, no agora da reminiscência e da escritura, o andar mais lento e o atraso em relação ao que acontece permite ao pensador uma conservação conceitual e política dos rastros do passado que não foram reconhecidos ainda. No próprio texto benjaminiano, encontramos:

Adotara mesmo o costume de ficar sempre meio passo atrás. Era como
se, em nenhum caso, quisesse construir um front, mesmo que com
minha própria mãe. O quanto tive de agradecer a essa resistência
sonhadora nos passeios em comum pela cidade, descobri mais tarde, ao
se abrir seu labirinto ao impulso sexual. Este, porém, com seu primeiro
tatear, buscava não o corpo, mas sim a pervertida Psique, cujas asas
brilhavam pútridas à luz de um lampião de gás ou dormitavam ainda
dobradas na peliça, na qual se transformara em crisálida. Beneficiei-me
então de um olhar que parecia não ver nem a terça parte do que, na
verdade, abrangia. (BENJAMIN, 1987, p. 126).

No excerto anterior, se defende a continuidade entre a alma do infante e a própria condição da borboleta capturada, em seu esplendor, pelo caçador. Humano e 
animal, na precedência do impulso sexual, o menino abjura sua própria mãe e sua classe, deixando-se capturar pelo convite que uma prostituta lhe fizera na rua. Esse murmúrio do passado, esse convite que a cidade lhe fizera só se tornou liberto do esquecimento na atividade de escrever. A política da escrita em Benjamin segue o primado de tentativa de recuo ao que fora, a partir do apelo que se faz temporalmente, na inauguração de um agora de cognoscibilidade. Essa reminiscência guarda profundas conexões com a tensão entre mística judaica e materialismo histórico. A abstrata continuidade do tempo é um invólucro de onde podem saltar imagens e murmúrios do que se vai soterrando por intermédio da versão hegemônica das sociedades e das próprias coisas. Um tempo espesso se desvia do risco das novidades recorrentes. É nesta direção que se pode retirar do pensamento de Benjamin uma fértil relação entre a infância e a dialética sagrado/profano. Um apelo que se faz à alma, um apelo de fervor e de dissolução da unidade de si. São os anjos, como auxiliares precários, que podem ter estado presentes naqueles momentos do passado em torno dos quais se desenham múltiplos círculos concêntricos, estendendo-se para conexões imprevisíveis. Há política encharcada de força no perigoso transtorno da felicidade, que ainda não foi continuada. Para as futuras gerações, a passagem furtiva de uma imagem do passado é, ao mesmo tempo, a oportunidade imprevista de lutar por uma história sufocada. Na brincadeira e na deambulação pela cidade, ajudantes irrisórios carregam a centelha de esperança que pode atear fogo nas certezas adultas e instituídas. Perder-se de si e de sua própria classe, embora perigoso e arriscado, é um modo de encontrar liames entre o que foi e o que advirá. Embebidos da aproximação ao sentido múltiplo da interpretação de textos sagrados, os escritos de Walter Benjamin defendem uma inusitada conceitualização da infância, já que desejo, morte e dissolução se fazem presentes nas camadas recuperáveis do próprio processo de elaboração de si.

Podemos considerar que a infância porta uma novidade mais próxima da concepção de atualidade em Walter Benjamin. Enquanto a novidade obedece ao fervor publicitário de oferecer às massas algo com que se entreterem de forma intermitente, a atualidade só se torna possível por intermédio do apelo a um público que ainda não existe. A atualidade nega a corrente de obviedade e continuísmo, que são fontes da teologia da mercadoria no capitalismo, e se assenta na contiguidade de objetos, no interstício entre o "já foi” e o "ainda, não". Crianças e anjos se entrecruzam nas possibilidades forjadas pela interrupção da cronologia. Benjamin forja/lembra de um infante que chega atrasado aos lugares, reconhecendo, tardiamente, o halo de magia e 
de exceção que configurava as próprias coisas. O pensador recupera o resto que não foi reconhecido na primeira vez em que se lançou um olhar para os objetos. Mesmo que esperança e reconstituição do tempo sejam raridades, a tarefa política que se coloca não se retrai diante da imprevisibilidade. O perigo da felicidade não atinge apenas o indivíduo e as coletividades, mas fundamentalmente, a própria classe dominante que ainda precisa se manter no comando, espezinhando as multiplicidades colonizadas na religião do capitalismo. Distraidamente, os anjos e as crianças desenham contornos irregulares ao que consideramos como salvação. Na rua, os filhos não seguem os passos daqueles que os antecedem e é a alma que acolhe a interpelação da alteridade radical. Aquele olhar que não atinge tudo, na memória ainda pode restituir um sentido menor que ainda exige desdobramento. A esperança existe para os seres inacabados, tocados sutilmente pela presença de anjos deformados, novos ou nem sempre apaziguadores.

\title{
Infância e a angeologia de Walter Benjamin
}

No encontro entre a infância e as aparições angelicais, pouco convencionais, dos escritos de Benjamin, parece haver a abertura e a introdução de outra relação com a iluminação. Nesse sentido, Schérer (2009) também nos lembra que a infância, como objeto específico de atenção na sociedade, foi inventada no século XVIII - o "século das luzes", anunciando "a exigência de sua pedagogização integral” (SCHÉRER, 2009, p. 18). A pedagogia iluminista tomou muito da atenção de Benjamin, que se dedicou a esmiuçar os diversos materiais - principalmente da literatura - que passaram a ser especificamente destinados à infância. No entanto, a iluminação que emana das experiências infantis parece justamente profanar essa grande Luz que fomenta um "saber sagrado", ou torna mais visíveis os jogos ilusórios que fazem parte do imenso escopo de atividades e materiais destinados a uma única versão da infância:

\begin{abstract}
A criança, objeto da solicitude das Luzes, receptáculo de seu saber, instrumento do progresso, torna-se fonte de uma iluminação de outra espécie. Por sua 'ingenuidade', ela escapa da limitação; por sua natureza, ela reúne em si o começo e o fim; ela desborda o tempo histórico no que diz respeito à meta a atingir e ao ideal. (SCHÉRER, 2009, p. 22).
\end{abstract}

Nesse sentido, ao evocar a imagem dos anjos, Benjamin não o faz para que estejam fixados nas representações moralizantes que vem sendo reiteradas através dos 
documentos históricos hegemônicos - que intencionam docilizar e imobilizar a infância em uma imagem única, livre de toda profanação da vida mundana -, mas para subvertêlas a partir da fragilidade e da fugacidade luminosa que as compõem. Seu pensamento dá a ver, portanto, o diálogo que a criança estabelece com a história, a cidade, em suma, os lugares que percorre, na contracorrente do pensamento iluminista que ascendeu com a consolidação da burguesia - que atestava a importância de criar um mundo e um tempo próprio e isolado para a infância. Assim, a atenção que as crianças atribuem aos detritos contrasta com a imperiosidade do crescimento industrial. "Nesses detritos", escreve o filósofo berlinense, "elas reconhecem o rosto que o mundo das coisas assume para elas, e só para elas" (BENJAMIN, 2012a, p. 257). Reordenando e atribuindo funções imprevisíveis para aquilo que elas têm nas mãos, ou nos ouvidos (ao ouvirem as histórias que lhes são contadas), as crianças constroem um mundo que escapa às idealizações da racionalidade adulta, um mundo permeável às oscilações políticas e sociais. É na possibilidade de "fazer história dos detritos da história" (BENJAMIN, 2009, p. 138) que o pensador parece encontrar certo terreno para o desenrolar do seu pensamento, estabelecendo um vínculo profícuo com o chão da infância - que não soterra os restos e destroços que não são inteligíveis pela perspectiva histórica universal, mas os regurgita. A esses destroços, dirige-se a atenção de crianças e de anjos.

A temporalidade dos anjos de Benjamin resguarda uma "destruição necessária", cuja importância se dá na introdução de pequenas cesuras no desenrolar da cronologia linear, são anjos que "só vivem no instante de seu hino" para se aniquilarem logo depois. É nesse sentido que Benjamin parece coadunar a noção de destruição e de salvação;

[...] destruição sempre recomeçada, pois sempre rapidamente caduca, da linguagem tão segura de si mesma dos bem-pensantes e dos bemapessoados. A verdade da operação crítica surge dessa união radical entre destruição e salvação: ao arrancar as palavras e as obras do contexto lenitivo que, às vezes o próprio autor, e, quase sempre a história literária tradicional se apressam em lhes emprestar, a crítica quebra sua unidade factícia e, simultaneamente, expõe sua força de estranheza e subversão. (GAGNEBIN, 1997, p. 126).

A angeologia em Walter Benjamin se conecta, em nossa argumentação, com a experiência da infância. Os infantes e os anjos precários condensam força e presença a serem lidas, na atualidade viva de um dos sentidos do tempo: a oportunidade de citar 
um passado oprimido e a esperança, como legado para as futuras gerações, dotadas de uma fraca força messiânica. Sob a ditadura de moralismos vigentes, a infância é objeto de precauções e cuidados ciosos de conter o que é imprevisível. Ainda inexpressa, a linguagem da infância é um hieróglifo, um rastro da convergência temporária entre o sagrado e o profano. As crianças jogam, salvando os objetos de seu destino óbvio, abandonando-se à incompletude e ao estranhamento. Voltar-se à infância não é estabelecer uma linha de continuidade entre o passado e o presente, é radicalizar a distância de si em relação a si mesmo ${ }^{5}$. Jogar com a tradição se distingue de submeterse a ela, ou mesmo, enraizar-se em factícios começos. A atualidade em Benjamin se aparenta com o que repete, diferindo-se, no entanto, de si mesmo. A cada vez, o tempo da brincadeira e da cisão entre o mundo dos adultos e o mundo das crianças evoca o reflexo e a refração do macrocosmo no microcosmo. Encontrando ressonâncias políticas e afetivas do mundo dos adultos na brincadeira infantil, no jogo infantil, o pensador parece defender uma relação profunda entre as vivências, presente na superfície do gesto e da palavra ainda incerta. Utilizando micrologicamente as imagens da infância - a sua mesma, a de sua geração - Benjamin desdobra um dos sentidos de atualidade. Poderíamos, inclusive, considerar o materialismo benjaminiano como teológico, como afirma Barrento (2005), ao estabelecer uma conjunção entre o pensamento de Benjamin e a poética de Paul Celan. O materialismo teológico interpreta objetos e sensações perecíveis no compasso do devir dos objetos e sensações. Neste sentido, o tempo que a experiência da infância demora para atravessar camadas de palavras e significações dos adultos constitui uma espécie de invólucro do que se torna escrito. Preserva-se e implode-se aquilo que é citado. Lidamos com uma experiência que não requer de nós apenas direção e controle, mas fundamentalmente, desvio.

A esperança, outro sentido do tempo, não nos afasta do atual, mas esboça um encaminhamento ao futuro. Desenha-se um perfil menos melancólico ou deslocado do próprio tempo da obra benjaminiana. Não podemos nos esquecer de que se trata,

\footnotetext{
${ }^{5}$ No texto A criança no limiar do labirinto, Gagnebin faz uma importante discussão acerca dessa descontinuidade intrínseca à atividade da rememoração, indicando ampliações éticas e políticas que estão em jogo nessa distinção do sujeito e do "eu". A relevância que a imagem da distância possui em Benjamin não é subtraída quando o filósofo se lança a escrever memórias da infância em Berlim; mas ao invés disso, foi exilado na cidade estrangeira Paris que surgiram muitas dessas narrativas. O exílio espacial encontrou ressonância com um certo exílio no tempo, impossível de ser descrito tal qual foi, mas que se insurge no presente como oportunidade de desestabilizar a superfície da história presente. Distante de sua terra natal, Benjamin é acometido por recordações de infância e as escreve como uma criança que entra, corajosamente, no labirinto: "como se soubesse, confusamente, que só poderá reencontrar-se se ousar perder-se" (GAGNEBIN, 2013, p. 91).
} 
também, de revolver as imagens do perigo iminente que a felicidade carrega em direção ao presente.

O milagre da infância não é apenas retórica do traço iluminista do pensamento benjaminiano, não possui caráter programático e não é um dogma. A novidade que a infância porta é disruptiva, incômoda e não está previamente adequada à sensibilidade de cuidadores e pedagogos. Na escrita de Walter Benjamin, as crianças são as testemunhas frágeis e não-totalizáveis da relação entre sagrado e profano. Sem abandonar a racionalidade de seu projeto investigativo, Walter Benjamin se apropria de aspectos da mística judaica a fim de defender uma concepção de tempo espesso, não cronológico. Na década de 1920, Walter Benjamin se dedica à articulação de uma publicação que nunca chegará a ver a luz do dia, a revista Angelus Novus. Ao final de um texto que serviria de indicação programática da publicação, Benjamin (2012b) faz afirmações que se coadunam com o que discutimos no presente artigo:

Há mesmo uma lenda talmúdica segundo a qual os anjos - a cada momento sempre novos, em legiões infinitas - são criados para, depois de terem entoado os seus hinos na presença de Deus, deixarem de existir e se dissolverem no nada. Que o nome desta revista sirva para mostrar que o sentido de atualidade que ela pretende representar é o único verdadeiro. (BENJAMIN, 2012b, p. 46)

Os anjos canhestros, recentes, fulgurantes são personagens que se avizinham do jogo e da perplexidade do infante diante da complexidade do mundo e da cidade. Portam uma mensagem de atualidade evanescente, que se conjuga com aquilo que foi, mas não recupera integralmente o olvido. A atualidade depende mais de uma atitude $\mathrm{e}$ menos de um apreço pelo destinatário. A novidade do nascimento porta menos a realização de uma expectativa do que um diálogo com o que não foi realizado alhures, antes. Mas a atualidade é efêmera, a cada oportunidade agarrada no decorrer do tempo histórico. Assim como a brisa e o calor de um dia de verão são captados transversalmente por quem lê e escreve, deslocado temporariamente justamente dos raios de sol e da brisa. Estudantes e crianças ensaiam aproximações com a fulguração de uma correspondência entre passado e presente. Brincar se aparenta com um desvio promissor em relação à objetividade reinante. Há uma atenção delicada em relação ao que é percebido e captado. A atitude que se desenha na brincadeira preserva, esquecendo aquilo que parecia essencial, mas não é captável de uma vez por todas. As sensações e as percepções minoritárias da infância preservam uma parte dos objetos e das vivências, embora aquilo que se preserve só retorne na assunção de uma distância 
de si em relação a si mesmo, no agora do exercício da escrita e no relampejo da recordação - citação - do passado. A preservação se coaduna com o esquecimento e não há recuo absoluto ao que fora experimentado. Trata-se de um salto, de uma expressão no tempo daquilo que, ontologicamente, foi perdido. Tateando com as mãos os objetos que já haviam sido úteis aos adultos, a criança garante um uso torto aos objetos, salvando-os da condição de mercadorias ou de potenciais mercadorias. O relampejo de uma face incomum dos objetos pode ser compreendido como uma expressão transitória do revide da experiência humana ao que há de mágico nos objetos. O pensador maneja materialmente signos do que encontrou na discussão sobre textos sagrados. Embora não encontremos uma explícita defesa de relação entre infância e religião em Walter Benjamin, podemos nos apropriar de alguns vestígios que, assistematicamente, indicam a defesa do sentido político da infância, coincidente com a fulguração da esperança e da abertura do tempo, problemas que garantem a migração da escrita do pensador de temas sagrados para a inquietação com temas imanentes a vida individual e social no limiar do século passado. Walter Benjamin nos ajuda a defender que a infância é uma oportunidade para que nos desviemos da obviedade das coisas e de nós mesmos. Ao aludir a uma experiência infantil, Benjamin (1987) nos fornece mais uma importante caracterização de um método mágico-materialista, reconhecível imediatamente no modo como se escreve, nos instrumentalizando em direção a perspicácia da ação e da brincadeira que se sobrepõe a qualquer soberania intelectiva. $\mathrm{O}$ pensador evoca os armários e as meias que se guardavam em alguns deles, desdobrando na planície da escrita a profundidade de uma recordação:

Era preciso abrir caminho até os cantos mais recônditos; então deparava minhas meias que ali jaziam amontoadas, enroladas e dobradas na maneira tradicional, de sorte que cada par tinha o aspecto de uma bolsa. Nada superava o prazer de mergulhar a mão em seu interior tão profundamente quanto possível. E não apenas pelo calor da lã. Era 'tradição' enrolada naquele interior que eu sentia em minha mão e que, desse modo, me atraía para aquela profundeza. Quando encerrava no punho e confirmava, tanto quanto possível, a posse daquela massa suave e lanosa, começava então a segunda etapa da brincadeira que trazia a empolgante revelação. Pois agora me punha a desembrulhar a 'tradição' de sua bolsa de lã. Eu a trazia cada vez mais próxima de mim até que se consumasse a consternação: ao ser totalmente extraída de sua bolsa, a 'tradição' deixava de existir. (BENJAMIN, 1987, p. 122).

Na continuidade do aforisma, Benjamin (1987) não se esquece de considerar que "forma" e "conteúdo" bem como "invólucro" e "interior" eram uma e a mesma 
coisa, embora se convertessem naquela terceira coisa que eram as próprias meias. Após conseguir desdobrar a imagem de uma brincadeira e da conversão por ela propiciada, o pensador ainda se dedicará a indicar o quanto foi se afastando da magia no seu percurso de crescimento, notando que apenas no "Estranho" ou no "Espantoso" ainda conseguia encontrar o pouso provisório do que era inquietante. $\mathrm{O}$ aforisma, no entanto, mostrando a não coincidência daquele que recorda com o que é recordado, enfoca o método que se origina da aproximação da tradição ao próprio corpo, ou seja, da abertura ao uso próprio e político daquilo que foi herdado, sejam livros, narrativas, esperanças ou mesmo temores. Ainda no mesmo aforisma, o pensador não economiza no exercício de defesa da atualidade do que sugere, garantindo, para nós, a possibilidade de defender uma ressonância entre sagrado e profano, entre o que foi perdido e o agora, entre o que foi esquecido e o que é lembrado. Afirma o pensador no aforisma que, "Tudo o que era guardado a chave permanecia novo por mais tempo. Mas meu propósito não era conservar o novo e sim renovar o velho.” (BENJAMIN, 1987, p. 124). A renovação se inicia como ato que traz para si o que foi transmitido, desdobra a partir de si o que restou. Trata-se de um método em que a experiência da infância é citada como uma das oportunidades de conexão entre tradição e presente, atualidade e passado, sagrado e profano.

\section{Considerações finais}

Há uma presença deslocada nas salas de aula, nos quartos, nos bairros, nas ruas cobertas de poeira e papéis. Paradoxalmente, o deslocamento é uma forma de relação possível com o tempo, sem que se torne um modelo a se seguir ou algo que possa se tornar administrável. A presença deslocada conversa, mesmo sem emitir sons inteligíveis, com o vestígio do que é sagrado. Não se trata de nos tornarmos condescendentes com as crianças e nem muito menos de concluirmos que a infância seja uma propriedade das crianças. Também o historiador materialista, na acepção de Benjamin, se conecta com a fulguração dos anjos. Em seu texto derradeiro - as Teses sobre o conceito de história - Benjamin cita o Anjo da História, alegoria de um exercício historiador. Assim o anjo é apresentado:

Há um quadro de Klee intitulado Angelus Novus. Representa um anjo que parece preparar-se para se afastar de qualquer coisa que olha fixamente. Tem os olhos esbugalhados, a boca escancarada e as asas 
abertas. $\mathrm{O}$ anjo da história deve ter esse aspecto. Voltou o rosto para o passado. A cadeia de fatos que aparece diante dos nossos olhos é para ele uma catástrofe sem fim, que incessantemente acumula ruínas sobre ruínas e lhas lança aos pés. Ele gostaria de parar para acordar os mortos e reconstituir, a partir dos seus fragmentos, aquilo que foi destruído. Mas do paraíso sopra um vendaval que se enrodilha nas suas asas, e que é tão forte que o anjo já não as consegue fechar. Esse vendaval arrasta-o imparavelmente para o futuro, a que ele volta as costas, enquanto o monte de ruínas à sua frente cresce até o céu. Aquilo a que chamamos o progresso é esse vendaval. (BENJAMIN, 2012b, p. 14).

A tese, tornada célebre pela proximidade entre a leitura feita sobre o quadro de Paul Klee e a atividade reminiscente da história materialista, apresenta mais um elemento para a consolidação da perspectiva crítica em Benjamin. O vendaval do progresso é a norma histórica que inviabiliza o reconhecimento dos vestígios do tempo que se incrustam nos objetos. O brinquedo e a infância são temas que podem ser interpretados à luz da perspectiva defendida na tese. $\mathrm{O}$ apelo do burburinho da cidade está presente nas lembranças de infância que Benjamin evoca em seus textos autobiográficos sobre o século XIX, bem como na atenção desajeitada das crianças ao que se mostra como desconexo ou inacabado. As crianças transformam objetos em brinquedos e recebem o sinal das gerações anteriores por intermédio dos brinquedos que lhes são ofertados. Aquilo que é político e histórico se apresenta as crianças nos objetos ofertados pelos adultos, a estranheza das situações em que as crianças se encontravam comunica um sentido que foi soterrado temporalmente, mas pode ser recolocado em evidência por intermédio da atividade reminiscente. Neste sentido, as crianças propiciam uma ambiência espessa aos adultos, seja no agora de uma composição textual sobre o presente, na partilha de uma vivência com o outro - aquele que ouve, que acolhe o que é dito - seja na recordação, que se estruturam como subsídios de uma construção da imagem do presente. A catástrofe do progresso desenha-se nas asas do Anjo da História, embora ele quisesse se demorar no recolhimento e reconhecimento do amontoado de mortos e ruínas que se avolumam. A séria atividade do historiador se aproxima, numa possível interpretação dos momentos da obra do pensador, das ações infantis que não se submetem ao dado, mas que insistem na composição de caminhos precários por entre as ruínas. Destruição e reconhecimento não compõem unidades que se possam separar definitivamente na elaboração do exercício histórico.

A que as crianças forjadas por Walter Benjamin nos chamam a atenção? Para a lembrança de que a esperança é mais um convite ao fazer do que ao negar-se ao tempo. 
$\mathrm{Na}$ brincadeira e na percepção infantil gostaríamos, talvez, de nos demorarmos. Mas elas surgem como a lacuna onde podemos nos distanciar de nós mesmos. Uma distância criada em relação a nós mesmos pode se dar politicamente, quando o que é arcaico ou impensado nos ajuda a colher, provisoriamente, a brisa do que podemos ansiar. Ao invés de supormos uma continuidade histórica entre passado, presente e futuro, Walter Benjamin sugere que adotemos um olhar político. Os fios de esperança que a brincadeira tece se coadunam com uma visada mágica sobre o tempo, encaminhando-se mais para a articulação de uma atitude do que para a reiteração de um saudosismo. Os anjos e seres limiares que se prontificam a aliar-se com as crianças furam a impressão de pureza ou docilidade em relação aos miúdos. Tal como a mulher que conversa com Fernand Deligny sobre as vozes dos moleques que pareciam uma espécie de delírio, identificamos nas crianças forjadas nos textos benjaminianos uma possibilidade de interrupção da continuidade, de conservação e destruição do que fora lembrado, de modo a insistir em uma conexão com o presente.

Recebido em: 15-02-2019

Aceito em: 11-03-2019

\section{Referências}

AGAMBEN, Giorgio. Infância e História: Destruição da experiência e origem da história. Belo Horizonte: Editora UFMG, 2005.

BARRENTO, João. Ler o que não foi escrito: Conversa inacabada entre Walter Benjamin e Paul Celan. Lisboa: Edições Cotovia, 2005.

BENJAMIN, Walter. Magia e técnica, arte e política: Ensaios sobre literatura e história da cultura. São Paulo: Brasiliense, 2012a.

BENJAMIN, Walter. O anjo da história. Belo Horizonte: Autêntica Editora, 2012b.

BENJAMIN, Walter. Reflexões sobre a criança, o brinquedo e a educação. São Paulo: Duas Cidades, Editora 34, 2009.

BENJAMIN, Walter. Obras escolhidas II: Rua de Mão Única. São Paulo: Editora Brasiliense. 1987.

BENJAMIN, Walter; SCHOLEM, Gershom. Correspondência. São Paulo: Editora Perspectiva. 1980.

DELIGNY, Fernand. Os vagabundos eficazes: Operários, artistas, revolucionários: educadores. São Paulo: n-1 edições, 2018.

GAGNEBIN, Jeanne Marie. Sete aulas sobre linguagem, memória e história. Rio de 
Janeiro: Imago, 1997.

GAGNEBIN, Jeanne Marie. História e narração em Walter Benjamin. São Paulo: Perspectiva, 2013.

LARROSA, Jorge. Pedagogia profana: Danças, piruetas e mascaradas. Belo Horizonte: Autêntica, 2016.

SCHERER, René. Infantis: Charles Fourier e a infância para além das crianças. Tradução João Guilherme de Freitas Teixeira. Autêntica, 2009. 